May 2000 • NREL/CP-520-27480

\title{
Testing to Support Improvements to PV Components and Systems
}

H. Thomas, B. Kroposki, and C. Witt National Renewable Energy Laboratory

W. Bower, R. Bonn, J. Ginn, and S. Gonzales Sandia National Laboratories

Presented at the $16^{\text {th }}$ European Photovoltaic Solar Energy Conference and Exhibition Glasgow, Scotland, U.K. May 1-5, 2000

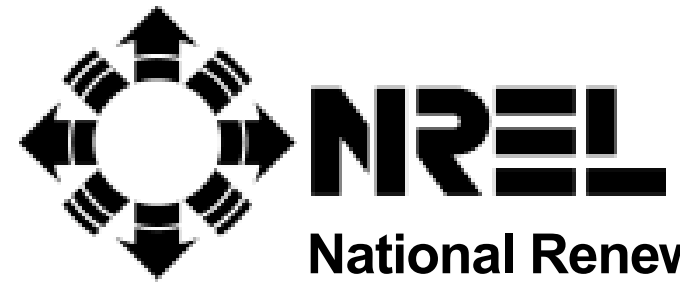

1617 Cole Boulevard Golden, Colorado 80401-3393

NREL is a U.S. Department of Energy Laboratory Operated by Midwest Research Institute $\bullet$ Battelle $\bullet$ Bechtel Contract No. DE-AC36-99-G010337 


\section{NOTICE}

The submitted manuscript has been offered by an employee of the Midwest Research Institute (MRI), a contractor of the US Government under Contract No. DE-AC36-99G010337. Accordingly, the US Government and MRI retain a nonexclusive royalty-free license to publish or reproduce the published form of this contribution, or allow others to do so, for US Government purposes.

This report was prepared as an account of work sponsored by an agency of the United States government. Neither the United States government nor any agency thereof, nor any of their employees, makes any warranty, express or implied, or assumes any legal liability or responsibility for the accuracy, completeness, or usefulness of any information, apparatus, product, or process disclosed, or represents that its use would not infringe privately owned rights. Reference herein to any specific commercial product, process, or service by trade name, trademark, manufacturer, or otherwise does not necessarily constitute or imply its endorsement, recommendation, or favoring by the United States government or any agency thereof. The views and opinions of authors expressed herein do not necessarily state or reflect those of the United States government or any agency thereof.

Available electronically at http://www.doe.gov/bridge

Available for a processing fee to U.S. Department of Energy and its contractors, in paper, from:

U.S. Department of Energy

Office of Scientific and Technical Information

P.O. Box 62

Oak Ridge, TN 37831-0062

phone: 865.576 .8401

fax: 865.576.5728

email: reports@adonis.osti.gov

Available for sale to the public, in paper, from:

U.S. Department of Commerce

National Technical Information Service

5285 Port Royal Road

Springfield, VA 22161

phone: 800.553 .6847

fax: 703.605.6900

email: orders@ntis.fedworld.gov

online ordering: http://www.ntis.gov/ordering.htm

Printed on paper containing at least $50 \%$ wastepaper, including $20 \%$ postconsumer waste 


\title{
TESTING TO SUPPORT IMPROVEMENTS TO PV COMPONENTS AND SYSTEMS
}

\author{
H. Thomas, B. Kroposki, C. Witt \\ National Renewable Energy Laboratory \\ 1617 Cole Boulevard \\ Golden, CO USA 80401-3393 \\ W. Bower, R. Bonn, J. Ginn, S. Gonzales \\ Sandia National Laboratories \\ 1515 Eubank SE \\ Albuquerque, NM USA 87185-0753
}

\begin{abstract}
:
The National Photovoltaic (PV) Program is sponsored by the U.S. Department of Energy, and includes a PV Manufacturing Research and Development (R\&D) project conducted with industry. This project includes advancements in PV components to improve reliability, reduce costs, and develop integrated PV systems. Participants submit prototypes, pre-production hardware products, and examples of the resulting final products for a range of tests conducted at several national laboratories, independent testing laboratories, and recognized listing agencies. The purpose of this testing is to use the results to assist industry in determining a product's performance and reliability, and to identify areas for potential improvement. This paper briefly describes the PV Manufacturing R\&D project; participants in the area of PV systems, balance of systems, and components; and several examples of the different types of product and performance testing used to support and confirm product performance.
\end{abstract}

Keywords: Inverter- 1: Balance of Systems- 2: Components- 3

\section{INTRODUCTION}

The U.S. Department of Energy (DOE), in cooperation with the U.S. photovoltaic (PV) industry, has the objective of enhancing the U.S. PV industry leadership in the manufacture and commercial development of PV products. To further this objective, the Photovoltaic Manufacturing R\&D project was initiated in 1990 between the DOE and the U.S. PV industry to help improve PV manufacturing processes and substantially reduce associated manufacturing costs. The project accomplishes these objectives by conducting competitive solicitations inviting proposals that address both technology-specific and generic problems in manufacturing R\&D identified by industry. Work is implemented through cost-shared contractual agreements between the federal government, through the DOE and the National Renewable Energy Laboratory (NREL), and individual members of the U.S. PV industry. Technical teams from the National Center for Photovoltaics (NCPV, which includes NREL and Sandia National Laboratories) manage the work.

The Manufacturing R\&D efforts are divided into two parts, with the majority of the work in the area of PV Module Manufacturing. Results of this work are described in other publications [1,2]. The contracted efforts in PV System and Components are more fully described in the paper, "Progress in Manufacturing R\&D in Photovoltaic Components and Systems," presented at this conference and in other publications $[3,4]$. The purpose of this paper is to review the variety of testing conducted in support of the PV systems and component R\&D included in the PV Manufacturing project.

There have been two solicitations for work in the PV System and Component portion of the PV Manufacturing project. Work under the first solicitation was initiated in 1995, with most work completed by 1998. Participants in this solicitation and their work are listed in Table I. As part

Table I: PV System and Component Manufacturing subcontracts initiated in 1995 and now completed.

\begin{tabular}{lll}
\hline Company & Title \\
\hline - & Ascension Technology, Inc. & Manufacture of an AC Photovoltaic Module \\
- & Advanced Energy, Inc. & Next-Generation Three-Phase Inverter \\
- $\quad$ Evergreen Solar, Inc. & Advanced Polymer PV System \\
- $\quad$ Omnion Power Engineering Corp. & Three-Phase Power Conversion System for Utility- \\
- $\quad$ Solar Design Associates, Inc. & Interconnected PV Applications \\
- Solar Electric Specialties & The Development of Standardized, Low-Cost AC PV \\
- Trace Engineering & Systems \\
- Utility Power Group, Inc. & Design, Fabrication, and Certification of Advanced Modular \\
& PV Power Systems \\
& Modular Bi-directional DC-to-AC Power Inverter Module \\
for PV Applications
\end{tabular}


Table II: System and Component Manufacturing R\&D subcontracts initiated during 1998.

\begin{tabular}{lll}
\hline Company & Title \\
\hline - $\quad$ Ascension Technology, Inc. & Cost Reduction and Manufacture of the SunSine ${ }^{\mathrm{TM}} 325 \mathrm{AC}$ \\
& Module \\
- $\quad$ Omnion Power Engineering Corp. & $\begin{array}{l}\text { Manufacturing and System Integration Improvements for One- } \\
\text { and Two-kilowatt Residential PV Inverters }\end{array}$ \\
- $\quad$ PowerLight Corp. & $\begin{array}{l}\text { PowerGuard } \\
\text { - }\end{array}$ \\
- Utility Power Group, Inc. & Development of a Fully-Integrated PV System for Residential \\
& Applications \\
\hline
\end{tabular}

of a later PV Manufacturing solicitation, new participants were competitively selected and new contracts negotiated in 1998. This work is still in progress. These participants are listed in Table II. Participants in both solicitations included a variety of tests to support the planned product advancements, validate product performance to specifications, and adherence to safety standards as part of their subcontract agreements.

\subsection{TESTING AND CHARACTERIZATION}

System and component testing is conducted in collaboration with the NCPV, through independent testing laboratories, and at listing agencies. Testing at NCPV laboratories, including NREL and Sandia, is a collaborative effort, with specific tests defined by agreement between the labs and the manufacturer. Often, special tests are included to evaluate a particular aspect of interest to the manufacturer or to meet a special requirement from a potential customer. The NCPV laboratories test, but do not certify products.

Engineers at the NCPV laboratories conduct tests on production prototypes to identify needed improvements, test final products to compare them to the planned specifications, and assess long-term performance and reliability. Industry engineers assist in defining the types of tests and are often present during the testing. Typically, the manufacturer also applies to a qualified laboratory for a product listing for safety, or in the case of utility-interactive products, to determine if the product meets interconnection guidelines. Industry also sends products, prototypes, and samples to a variety of independent laboratories for failuremode testing and specialized design evaluations. All these tests are in addition to the manufacturer's own specialized, in-house testing. The tests summarized in the following sections are only a few examples of the variety of tests conducted to establish a component's or system's performance and reliability.

\subsection{Characterization and Evaluation at Sandia}

Sandia evaluates prototypes and production components and systems in collaboration with the Manufacturing R\&D project. Sandia evaluates the product relative to its performance specifications and assesses the design to meet certain safety and performance standards. The Sandia PV Photovoltaic Systems Evaluation Laboratory (PSEL) is located in Albuquerque, New Mexico. Products that have been tested include: a $60-\mathrm{kW}$ hybrid inverter and a 30-kW grid-tied inverter from Advanced Energy, Inc.; a 15-kWrated Integrated Power Processing Unit (IPPU) from Utility Power Group, Inc.; a 4-kW single-phase, packaged hybrid system from Solar Electric Specialties (now part of Applied Power Corp.); a 250-W SunSine module-scale inverter from
Ascension Technology, Inc. (now a division of Applied Power Corp. [APC]); and a 250-W module-scale inverter from Advanced Energy, Inc., under a Solar Design Associates subcontract. Several subcontracts are still in progress. Of these, Ascension will send Sandia their preproduction prototype and production versions of the new SunSine ${ }^{\mathrm{TM}}$ module-scale inverter, which incorporates their new soft-switching technology. Utility Power Group, Inc., will be sending their $12.9-\mathrm{kW}$ grid-interactive inverter and energy storage unit for evaluation. The evaluation of the Omnion Model 3300 (100-kVA) grid-tied inverter is an example evaluating one production prototype from the Manufacturing R\&D project.

As part of their contract, Omnion Power Engineering Corporation (now a division of S\&C Electric Company) delivered the pre-production prototype Model 3300 power conversion system (PCS) inverter, developed as part of this agreement. Sandia operated the inverter with a PV array (up to $25 \mathrm{~kW}_{\mathrm{dc}}$ ) and a battery bank (over $100 \mathrm{~kW}$ ) to conduct a series of tests. Test results confirmed that the unit met planned operating specifications, and several results are highlighted here. Omnion anticipated an inverter efficiency of $95 \%$, without the transformer. Sandia measured $93 \%$ to $94 \%$, with the transformer, at input power levels above 15 $\mathrm{kW}$. Because a transformer requires some power, these results support the Omnion figure. Total harmonic distortion (THD) of the output current, expressed as a fraction of the inverter's rating, was below $4 \%$ for all power levels above $5 \mathrm{~kW}$, supporting the company's specification of $<5 \%$. The voltage THD of the utility line at the test facility remained below $2 \%$ for all conditions tested. The maximum-powertracker circuitry accurately extracted the maximum available from the test PV array. Acoustic noise was $63 \mathrm{~dB}$, considered extremely low for a $100-\mathrm{kW}$ inverter. The cooling fans effectively maintained the heat-sink temperature below $50^{\circ} \mathrm{C}$, with a $25^{\circ} \mathrm{C}$ ambient operating temperature. As would be expected for prototype testing, Sandia also identified areas needing improvement. The conducted radio-frequency interference (RFI) exceeded the maximum allowed by the Federal Communications Commission (FCC), and additional filtering was recommended. However, the radiated RFI was negligible in the frequency spectrum relevant to FCC Part 15. Sandia noted the high-frequency trip point was set at $60.5 \mathrm{~Hz}$, in accordance with an earlier draft version of Institute for Electrical and Electronic Engineers (IEEE) P929. Omnion will adjust the unit to $61.0 \mathrm{~Hz}$, to comply with IEEE 9292000. Sandia also noted that the low-AC-voltage trip point was set at $3 \%$ below nominal. The lab noted that this is much more conservative than the $10 \%$-below-nominal specification. Investigators recommended an adjustment because the higher trip point could result in unnecessary interruption in inverter operation. Overall, Sandia reported 
that no operational difficulties were encountered. Omnion made the indicated modifications to the revised PCS Model 3300 and is working to obtain an Underwriters Laboratories (UL) listing for product safety [5]. An added benefit of testing this unit was that it provided the first opportunity to evaluate a large, grid-tied inverter for anti-islanding with a resonant resistive-inductive-capacitive (RLC) local load (i.e., part of the new IEEE 929-2000 interconnection standard). The inverter disconnected under a variety of loads within the time required by IEEE 929-2000. These test results are part of Omnion's Annual Technical Progress Report [6] and are also reported on the Sandia website [5]. An illustration of the Sandia testing setup is shown in Figure 1 .

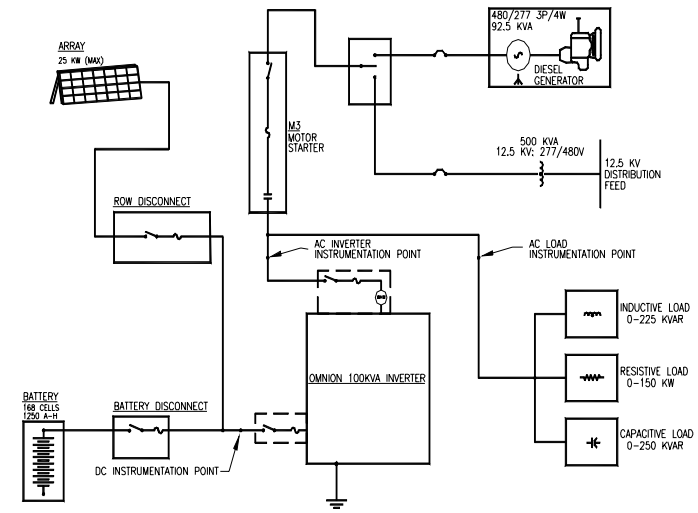

Figure 1. Diagram of test setup at Sandia's PSEL for the Omnion PCS Model 3300.

\subsection{Accelerated Environmental Testing and Long-Term Performance Evaluation at NREL}

NREL conducts accelerated environmental testing and long-term performance evaluations of PV modules and components at its Outdoor Test Facility (OTF), located in Golden, Colorado. NREL conducts performance testing and evaluation of products and systems in progress or resulting from the project. Products and components that NREL evaluated for the project include: a Modular Autonomous PV Power Supply from Solar Electric Specialties (now a part of Applied Power Corporation), the 250-Wac SunSine ${ }^{\mathrm{TM}} 300$ AC PV Module from Ascension/APC; a 250Wac module-scale inverter from Advanced Energy; and PowerCurb ${ }^{\mathrm{TM}}$ components from PowerLight Corp. Products still planned for testing include two Trace Engineering 2.5kW Model PS inverters and the new 275-Wac SunSine ${ }^{\mathrm{TM}}$ AC PV Module from Ascension/APC. NREL also provided testing facilities for on-site valuations by UL. NREL's National Wind Center tested a prototype $60-\mathrm{kW}$ hybrid inverter resulting from a subcontract with Advanced Energy. The unit was connected to a generator, a wind simulator, and a battery bank to evaluate its ability to manage hybrid operating conditions. The evaluation of Ascension/APC's SunSine ${ }^{\mathrm{TM}} 300 \mathrm{AC}$ PV Module is an example of long-term performance testing at NREL's OTF. Figure 2 illustrates the test apparatus for the SunSine ${ }^{\mathrm{TM}} 300$ AC PV Module and Advanced Energy's module-scale inverter.

As part of the 1995 subcontract, Ascension/APC delivered pre-production and production versions of their SunSine ${ }^{\mathrm{TM}} 300$ AC PV Module for accelerated testing and long-term performance and reliability tests. This product consists of a 250-Wac module-scale inverter factory- mounted to an ASE Americas large-area PV module. NREL conducted accelerated environmental testing by cycling the entire AC PV Module between $-40^{\circ}$ to $+90^{\circ} \mathrm{C}$ for 30 cycles of 24 hours per cycle. Measurements under Standard Test Conditions were made before and after testing. NREL reported the inverter operated at full power $(250 \mathrm{Wac})$ over the testing period, and no changes in performance were detected. Ascension/APC requested this test to establish a level of confidence that the SunSine ${ }^{\mathrm{TM}} 300$ 's inverter would pass the same tests required for the PV module.

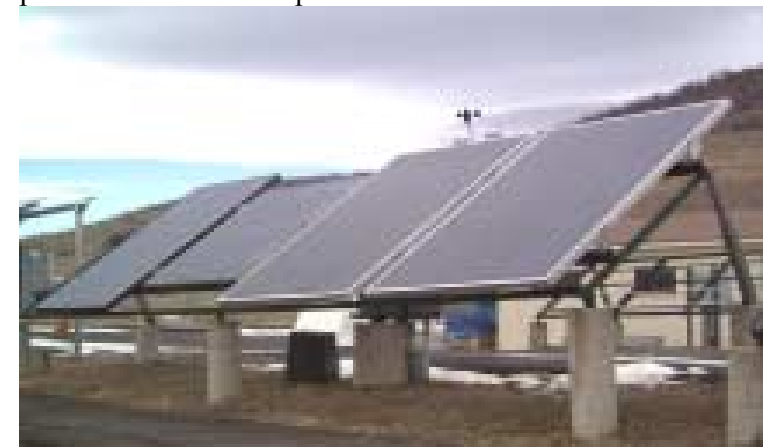

Figure 2: The SunSine ${ }^{\mathrm{TM}} 300 \mathrm{AC}$ PV Module and Advanced Energy's module-scale inverter under test at NREL's Outdoor Test Facility.

Test results also provided an indication of the expected reliability of the inverter. Pre-production prototypes and production versions of the SunSine ${ }^{\mathrm{TM}} 300$ AC PV Module were also tested for long-term performance and reliability. The products were mounted on outdoor racks at the OTF, connected to the grid, and instrumented to monitor the unit's performance under prevailing weather conditions in Colorado. Data collected include irradiance, wind speed, AC power output, PV module temperature, SunSine ${ }^{\text {TM}} 300$ inverter temperature, and capacitor temperature. Power output from the product and temperatures are collected every 5 seconds and averaged every 15 minutes. These SunSine ${ }^{\mathrm{TM}} 300$ AC PV Modules are still under test, and based on the data, they have operated without anomaly since installation in early 1999. Initial results are more fully described in Ascension/APC's Final Report for this contract [7]. NREL is also conducting specific subcomponent tests for Ascension/APC's new product, a 275-Wac module-scale inverter now termed the SunSine ${ }^{\mathrm{TM}}$. Ascension/APC requested this test to provide data for estimating this new product's lifetime and to begin to evaluate its long-term performance.

2.3 Failure Modes and Reliability Testing by Independent Test Laboratories

Manufacturers have also used a variety of independent testing laboratories to evaluate their products. One of these laboratories, QualMark Corporation, has a testing approach that several manufacturers have used, or plan to use, to evaluate the failure modes of their products. QualMark's testing plans include two specialized tests: a HALT (Highly Accelerated Life Test) and a HASS (Highly Accelerated Stress Screening). The QualMark HALT is a test regime typically requested by the manufacturer for pre-production prototypes. The testing rationale is that when the product is stressed beyond its design limits and parts begin to fail, the result can be a list of design corrections to improve the product's reliability. The tests are not pass/fail, but are used to optimize the design. Two participants in the 
Manufacturing R\&D project, Advanced Energy and Ascension/APC, submitted their inverters to these tests, with Sandia's support [8]. Both companies discovered several areas for improvement. Ascension/APC notes, "The HALT supported by Sandia and NREL was very useful in weeding out potential failure modes in our SunSine ${ }^{\mathrm{TM}} 300$ AC PV Module. We used HALT to achieve the highest possible reliability in the electronic design of our product. In the first 300 units built, only one unit had a failure in the electronics." Recently, Ascension/APC submitted the revised SunSine ${ }^{\mathrm{TM}}$ inverter for the HALT, and Utility Power Group will be submitting their $12.9-\mathrm{kW}$ inverter later this year as part of their contractual agreements.

Other types of testing are also important. One manufacturer, PowerLight Corporation, included wind testing as part of their product validation. PowerLight's product, termed PowerGuard ${ }^{\mathbb{B}}$, is a PV system that is mounted on a roof without roof penetrations. The unique product has two options for orienting the PV panels on the roof, either parallel to the roof or sloped, to better capture the available sunlight at higher latitudes. PowerLight had several versions of their angled-product design evaluated for wind resistance. They also evaluated scale models to test other methods of attaching PV laminates to their unique substrate. The product design was required to meet several constraints in addition to wind resistance, including low cost and an ability to collapse flat for a high packing-density for shipping. Results of these wind tests helped PowerLight engineers evaluate the lift and turbulence created by different design options, modify test designs and to then verify their final choice.

\subsection{Listing and Certification at Recognized Laboratories}

\subsubsection{Underwriters Laboratories Inc. ${ }^{\circledR}$}

As part of the subcontract agreements, manufacturers have investigated obtaining UL, ETL (by Intertek Testing Services), or other recognized listing as an indication of product safety. Most companies in the project chose to apply for an UL-listing of their products, as the UL Mark is often the most readily recognized by building inspectors and other local authorities. A safety listing is obtained when samples of the product have been tested and evaluated by a certified listing agency, and they comply with appropriate standards. Products may then carry the listing mark. UL makes their listing determination based on product testing, and if the product has a novel design, listing may be based on a design review compared to known criteria. Several novel products have resulted from the PV Manufacturing R\&D project and have required additional testing. These products ranged from the Ascension 250-W SunSine ${ }^{\mathrm{TM}}$ up to the Omnion 100-kW PCS Model 3300.

\subsubsection{CE (Conformite Europeenne) Marking}

The CE Marking is an official mark required by the European Community for electric equipment regulated by the European health, safety, and environmental protection directives. A product usually requires this Marking if it is to be sold in Europe. Two companies included an assessment of their designs to meet the CE Marking requirements as part of their contractual agreements. Ascension/APC reviewed their new SunSine ${ }^{\mathrm{TM}}$ design to define the modifications that would be necessary to obtain the CE Marking, but will not include those changes in the first production run. PowerLight determined and made the necessary modifications to their system to meet the $\mathrm{CE}$ Marking requirements, and that Marking has been received.

\section{CONCLUSIONS}

Testing and verification are key elements to support the results of the PV Manufacturing R\&D project. These tests are included as part of the contractual agreement, and they are defined in collaboration with the testing engineers and the manufacturer. Their purpose is to support industry in building advanced, reliable PV products and systems. The examples presented here illustrate the range of these tests. Manufacturers rely on these results to validate their products and to establish performance and reliability information. These results also provide data to support product warranties and guarantees. Testing to evaluate performance, qualify products for safety, and estimate product lifetimes will continue to be an essential part of this project.

\section{ACKNOWLEDGMENTS}

This work is supported under DOE Contract DE-AC3699GO10337 with NREL, a national laboratory managed by Midwest Research Institute, and Contract DE-AC0494AL8500 with Sandia National Laboratories, a multiprogram laboratory operated by Sandia Corporation, a Lockheed Martin Company. Many people have contributed to developing and implementing the PV Photovoltaic Manufacturing R\&D project and to the efforts carried out in this project. The authors acknowledge that this paper represents their work.

\section{REFERENCES}

[1] Witt, C. E., Mitchell, R. L., Symko-Davies, M., Thomas, H. P., King, R., and Ruby, D. S., 1999, "Current Status and Future Prospects for the PV Manufacturing Technology," Proceedings, $11^{\text {th }}$ International Photovoltaic Science and Engineering Conference (PVSEC-11), T. Saitoh, ed. (to be published)

[2] Witt, C. E., Mitchell, R. L., Thomas, H. P., Symko-Davies, M., King, R., and Ruby, D. S., 1998, "Manufacturing Improvements in the Photovoltaic Manufacturing Technology (PVMaT)," Proceedings, $2^{\text {nd }}$ World Conference and Exhibition on Photovoltaic Solar Energy Conversion, J. Schmid et al., ed., European Commission, Ispra, Italy, Vol. 2, pp. 1969-1973.

[3] Thomas, H. P., Kroposki, B., Witt, C. E., Bower, W., Bonn, R., and Ginn, J., 2000, "Progress in Manufacturing R\&D in Photovoltaic Components and Systems," Proceedings, $16^{\text {th }}$ European Photovoltaic Solar Energy Conference and Exhibition (to be published)

[4] Thomas, H. P., Kroposki, B., McNutt, P., Witt, C. E., Bower, W., Bonn, R., and Hund, T. D., 1998, "Progress in Photovoltaic System and Component Improvements," Proceedings, $2^{\text {nd }}$ World Conference and Exhibition on Photovoltaic Solar Energy Conversion, J. Schmid et al., ed., European Commission, Ispra, Italy, Vol. 2, pp. 1930-1935.

[5] Ginn, J.W., Bonn, R.H., and Sittler, G., "Inverter Testing at Sandia National Laboratories," Albuquerque, NM, Available at http://www.sandia.gov/pv (1999).

[6] Porter, D., Meyer, H., and Leang, W., Three-Phase Power Conversion System for Utility-Interconnected $P V$ Applications, A PVMaT Phase I Technical Progress Report, NREL, Golden, CO, NREL/SR-520-24095, February 1998.

[7] Kern, G., SunSine TM300: Manufacture of an AC Photovoltaic Module, Final Report, NREL, Golden, CO NREL/SR-520-26085, March 1999.

[8] Quarterly Highlight of Sandia's Photovoltaic Program, Volume 3, Dec. 1998, Sandia National Laboratories, Albuquerque, NM. 


\section{REPORT DOCUMENTATION PAGE}

Form Approved OMB NO. 0704-0188

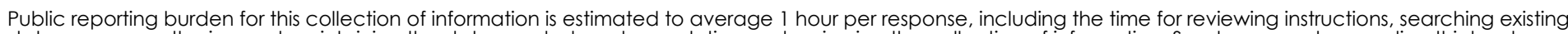

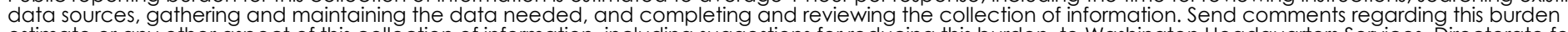

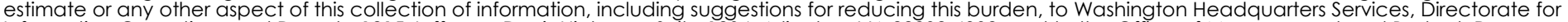

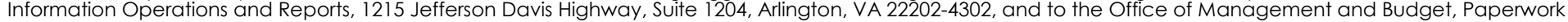
Reduction Project (0704-0188), Washington, DC 20503.

\begin{tabular}{|l|l|l|l}
\hline 1. AGENCY USE ONLY (Leave blank) & $\begin{array}{l}\text { 2. REPORT DATE } \\
\text { May } 2000\end{array}$ & $\begin{array}{l}\text { 3. REPORT TYPE AND DATES COVERED } \\
\text { conference paper }\end{array}$ \\
\hline
\end{tabular}

4. TITLE AND SUBTITLE

Testing to Support Improvements to PV Components and Systems

6. AUTHOR(S)

H. Thomas, B. Kroposki, C. Witt, W. Bower, R. Bonn, J. Ginn, S. Gonzales

7. PERFORMING ORGANIZATION NAME(S) AND ADDRESS(ES)

7. PERFORMING ORGANIATION NAME(S) AND ADDRESS(ES)

9. SPONSORING/MONITORING AGENCY NAME(S) AND ADDRESS(ES)

National Renewable Energy Laboratory

1617 Cole Blvd.

Golden, CO 80401-3393

conference paper

5. FUNDING NUMBERS

C

TA: PV006101

8. PERFORMING ORGANIZATION REPORT NUMBER

10. SPONSORING/MONITORING AGENCY REPORT NUMBER

CP-520-27480

11. SUPPLEMENTARY NOTES

12a. DISTRIBUTION/AVAILABILITY STATEMENT

National Technical Information Service

12b. DISTRIBUTION CODE

U.S. Department of Commerce

5285 Port Royal Road

Springfield, VA 22161

13. ABSTRACT (Maximum 200 words)

The National Photovoltaic (PV) Program is sponsored by the U.S. Department of Energy, and includes a PV Manufacturing Research and Development (R\&D) project conducted with industry. This project includes advancements in PV components to improve reliability, reduce costs, and develop integrated PV systems. Participants submit prototypes, pre-production hardware products, and examples of the resulting final products for a range of tests conducted at several national laboratories, independent testing laboratories, and recognized listing agencies. The purpose of this testing is to use the results to assist industry in determining a product's performance and reliability, and to identify areas for potential improvement. This paper briefly describes the PV Manufacturing R\&D project; participants in the area of PV systems, balance of systems, and components; and several examples of the different types of product and performance testing used to support and confirm product performance.

14. SUBJECT TERMS

photovoltaics ; inverter ; balance of systems ; components

5. NUMBER OF PAGES

17. SECURITY CLASSIFICATION

OF REPORT

Unclassified
18. SECURITY

CLASSIFICATION

OF THIS PAGE

Unclassified
19. SECURITY CLASSIFICATION OF ABSTRACT

Unclassified
20. LIMITATION OF ABSTRACT

UL 